\title{
造血器疾患に伴う細菌感染症の実態
}

\section{-10 年間の推移一}

阪神造血器疾患感染症研究グループ

近畿大学第 3 内科
堀内
大阪府立成人病センター第 5 内科
正岡 徹 柴田 弘俊
大阪大学微生物病研究所臨床部門内科
木谷 照夫 $\quad$ 田川 進一
国立大阪病院内科
川越 裕也 平田 充彦
大阪大学第 2 内科
米沢 毅 金山 良男

\author{
大阪市立大学臨床検査医学 \\ 巽 典之 任 太性 \\ 大阪医科大学第 2 内科 \\ 陰山 克 大藪 博 \\ 大阪赤十字病院内科 \\ 赤坂 清司 那須 芳 \\ 関西医科大学第 1 内科 \\ 安永幸二郎 藤竹 英樹 \\ 兵庫医科大学第 2 内科 \\ 永井 清保 金丸 昭久
}

(平成 1 年 8 月 7 日受付)

(平成 1 年 8 月 18 日受理)

Key words : hematopoietic disorder, bacterial infection sepsis suspected, antibiotic-therapy, neutropenia

\section{要旨}

阪神造血器疾患感染症研究グループで過去 10 年間に扱った細菌感染症 2,119 例について検討した. 基礎

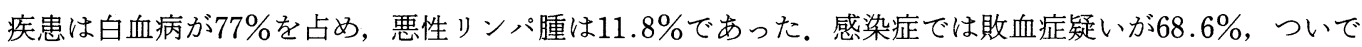
気道感染症, 敗血症の順であった。気道感染症や尿路感染症は徐々に減少傾向を示した。起炎菌は532菌 株が明らかにされた。グラム陰性菌 $62.8 \%$ ，グラム陽性菌 $36.5 \%$ であったが，最近 4 年間はグラム陽性 菌が優位であった. E. coli, Klebsiella 属などは減少傾向を示したが, Pseudomonas 属はほとんど変化し なかった. Staphylococcus 属, Streptococcus 属, Enterococcus 属はいずれも増加傾向を示した。 とくに 第三世代のセフェム系抗生剂が使用されてからこの傾向が強くなった。

抗生剂は23種が単独投与された. 有効率は $50 \%$ 台が多かった。 有効率と末梢好中球数は密接に関係し, とくに抗腫瘍剤投与後の nadir 期から回復する時期に有効率が上昇した. 好中球数が $500 / \mu 1$ 以下で治療 後も回復しない症例の有効率は $45.9 \%, 100 / \mu 1$ 以下で治療後も回復しない症例のそれは $36.0 \%$ でっ た.

\section{はじめに}

造血器疾患に合併する感染症は重篤に陥りやす く，その予防と治療は原疾患の寛解率に大きく影 響する。1979年，阪神地区の施設が集まり，感染

別刷請求先：(干589)大阪府大阪狭山市大野東377-2 近畿大学医学部第 3 内科堀内 篤
症の治療の研究を開始した。その後参加施設が増 え, 症例数も増加した。満 10 年が経過し, 扱った 症例数が 2,000 例を越えたのを機会に，今までの データーを整理し, 造血器疾患に合併する細菌感 染症の実態と治療成績についてまとめた結果を報 告する。 
Table 1 Distribution of sex and age

\begin{tabular}{lccc}
\hline & $\begin{array}{c}\text { Former phase } \\
(1979 \sim 1981)\end{array}$ & $\begin{array}{c}\text { Middle phase } \\
(1982 \sim 1984)\end{array}$ & $\begin{array}{c}\text { Late phase } \\
(1985 \sim 1988)\end{array}$ \\
\hline Male : Female & $334: 225$ & $434: 239$ & $494: 339$ \\
Age (yrs.) & $7 \sim 85$ & $12 \sim 82$ & $12 \sim 85$ \\
Mean age (yrs.) & 42.5 & 42.2 & 45.1 \\
\hline
\end{tabular}

\section{対象症例}

造血器疾患の観察中に発熱がみられた症例の中 で, 薬剤や輸血の副作用, 真菌あるいはウイルス 感染が明らかなもの, 腫瘍熱叔よび抗生剤投与後 6 日以内に死亡したものなどを除いた 2,119 例を 対象とした。観察期間は，1979年 9 月から1988年 6 月までの 10 年間で，この期間を便宜上前期 （1979 1981年），中期（1982１984年），後期 （1985～1988年）の 3 期に分けて検討した。各期に 扱った症例の性別，年齢，平均年齢を Table 1 に 示した。

\section{観察方法}

合併した感染症の種類, 起炎菌の種類, 各種抗 生剂の効果などについて検討した。起炎菌の検索 は動静脈血, 喀痰, 咽頭ぬぐい液, 尿, 䔬便の他 に, 化膿巣がある場合は直接局所から検体を採取 した。

用いられた抗生剂は23種で，いずれも単独に静 脈内に投与された。その他に Aztreonam と他剂 の併用効果をみるために， 3 通りの投与が行われ た。 た, 先行投与抗生剂の効果が不十分の場合 に，先行薬に上のせ併用してもよいことにした。 1 日投与量は，好中球減少例が大部分であること を考慮して, 普通使用量の $2 \sim 3$ 倍量を $2 \sim 3$ 回 に分けて点滴静注した。

臨床効果の判定は高久ら ${ }^{1} の$ 基準に従った。

著効：投与開始後 3〜4 日以内に平熱まで解熱 し,さらにその状態が 3 日間以上続き, 感染症に 伴ら臨床症状および検査所見が改善したもの.

有効：投与開始後 $3 \sim 4$ 日目までに有意に解熱 し,さらにその状態が 3 日間以上続き, 感染症に 伴ら臨床症状および検査所見が改善したもの.

やや有効：投与開始後 6 日目までに解熱傾向を 示し, 臨床症状および検查所見に改善傾向がみら
れたもの.

無効：投与開始後 6 日目までに解熱傾向がみら れず, 感染症に伴ら臨床症状および検査所見の不 変または増悪したもの。また，3〜4日目までに 解熱効果がみられず他剂に変更したもの.

以上の効果判定はまず主治医が行い, 最終判定 は研究グループ各施設の代表者の協議で決定し た。

1. 基礎疾患の種類

\section{結果}

10年間に扱った感染合併例の基礎疾患名を Table 2 に示した．急性骨髄性白血病 (FAB 分類 の M1，M2）が648例 (30.6\%) でもっとも多く, ついで急性リンパ性白血病289例 (13.6\%), 非 Hodgkin リンパ腫210例 (9.9\%)，慢性骨髄性白血 病の主として急性転化例170例 (8.0\%)，急性前骨 髄球性白血病（FAB 分類の M3）121例（5.7\%） の順であった。 3 期を比較すると, 頻度が高い疾 患は汪とんど差がなかったが，骨髄異形成症候群 と成人 $\mathrm{T}$ 細胞性白血病が増加傾向を示した。な お，後期で全体の患者数が増加したのは，グルー プの参加施設が増えたためである。

\section{2. 感染症の種類}

造血器疾患に合併した感染症を Table 3 に示 した. もっとも多かったのは敗血症疑いであり， 68.6\%を占めた。これは感染病巣が明らかでない が, 感染がもっとも疑われる高熱の持続例である. 参加施設の増加とともに敗血症疑いも増加した。 敗血症は $8.4 \%$ に認められ，3 期で大きな差はな かった。気道感染症は上気道と下気道を併せると， 全体で $14.8 \%$ みられたが，3期を比較すると前期 $20.6 \%$ ，中期 $14.2 \%$ ，後期 $11.1 \%$ と減少した。尿

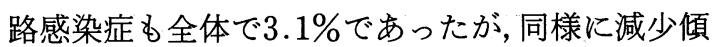
向を示した。 
Table 2 Underlying diseases and number of patients

\begin{tabular}{|c|c|c|c|c|c|c|c|c|}
\hline \multirow{2}{*}{ Underlying diseases } & \multicolumn{2}{|c|}{ Former phase } & \multicolumn{2}{|c|}{ Middle phase } & \multicolumn{2}{|c|}{ Late phase } & \multicolumn{2}{|c|}{ Total } \\
\hline & No. & $(\%)$ & No. & $(\%)$ & No. & $(\%)$ & No. & $(\%)$ \\
\hline Acute myeloblastic leukemia & 90 & $(31.1)$ & 211 & $(31.3)$ & 247 & $(29.6)$ & 648 & $(30.6)$ \\
\hline Acute promyelocytic leukemia & 51 & $(8.4)$ & 40 & $(5.9)$ & 30 & $(3.6)$ & 121 & $(5.7)$ \\
\hline Acute myelomonocytic leukemia & 14 & $(2.3)$ & 25 & $(3.7)$ & 44 & $(5.3)$ & 83 & $(3.9)$ \\
\hline Acute monocytic leukemia & 40 & $(6.6)$ & 30 & $(4.5)$ & 37 & $(4.4)$ & 107 & $(5.0)$ \\
\hline Erythroleukemia & 21 & $(3.4)$ & 20 & $(3.0)$ & 17 & $(2.0)$ & 58 & $(2.7)$ \\
\hline Acute lymphocytic leukemia & 66 & $(10.8)$ & 108 & $(16.0)$ & 115 & $(13.8)$ & 289 & $(13.6)$ \\
\hline Adult $\mathrm{T}$ cell leukemia & 7 & $(1.1)$ & 12 & $(1.8)$ & 29 & $(3.5)$ & 48 & $(2.3)$ \\
\hline Myelodysplastic syndrome & 7 & $(1.1)$ & 20 & $(3.0)$ & 57 & $(6.8)$ & 84 & $(4.0)$ \\
\hline Atypical leukemia & 4 & $(0.7)$ & 9 & $(1.3)$ & 14 & $(1.7)$ & 27 & $(1.3)$ \\
\hline Chronic myelocytic leukemia & 71 & $(11.6)$ & 41 & $(6.1)$ & 58 & $(6.9)$ & 170 & $(8.0)$ \\
\hline Chronic lymphocytic leukemia & 3 & $(0.5)$ & 2 & $(0.3)$ & 3 & $(0.4)$ & 8 & $(0.4)$ \\
\hline Chronic myelomonocytic leukemia & 0 & $(0.0)$ & 3 & $(0.4)$ & 0 & $(0.0)$ & 3 & $(0.1)$ \\
\hline Hodgkin's disease & 12 & $(2.0)$ & 18 & $(2.7)$ & 10 & $(1.2)$ & 40 & $(1.9)$ \\
\hline Non-Hodgkin lymphoma & 53 & $(8.7)$ & 64 & $(9.5)$ & 93 & $(11.1)$ & 210 & $(9.9)$ \\
\hline Multiple myeloma & 13 & $(2.1)$ & 20 & $(3.0)$ & 20 & $(2.4)$ & 53 & $(2.5)$ \\
\hline Other malig. disease & 11 & $(1.8)$ & 5 & $(0.7)$ & 14 & $(1.7)$ & 30 & $(1.3)$ \\
\hline Aplastic anemia & 28 & $(4.6)$ & 33 & $(4.9)$ & 37 & $(4.4)$ & 98 & $(4.6)$ \\
\hline Agranulocytosis & 4 & $(0.7)$ & 5 & $(0.7)$ & 3 & $(0.4)$ & 12 & $(0.6)$ \\
\hline Myelofibrosis & 6 & $(1.0)$ & 4 & $(0.6)$ & 3 & $(0.4)$ & 13 & $(0.6)$ \\
\hline Others & 9 & $(1.5)$ & 4 & $(0.6)$ & 4 & $(0.5)$ & 17 & $(0.8)$ \\
\hline Total & 610 & $(100.0)$ & 674 & $(100.0)$ & 835 & $(100.0)$ & 2119 & $(100.0)$ \\
\hline
\end{tabular}

Table 3 Infectious diseases

\begin{tabular}{|c|c|c|c|c|c|c|c|c|}
\hline & \multicolumn{2}{|c|}{ Former phase } & \multicolumn{2}{|c|}{ Middle phase } & \multicolumn{2}{|c|}{ Late phase } & \multicolumn{2}{|c|}{ Total } \\
\hline & No. & (\%) & No. & (\%) & No. & (\%) & No. & (\%) \\
\hline Sepsis & 49 & $(8.0)$ & 55 & $(8.2)$ & 74 & $(8.9)$ & 178 & $(8.4)$ \\
\hline Sepsis suspected & 381 & $(62.5)$ & 455 & ( 87.5$)$ & 618 & $(74.0)$ & 1454 & $(68.6)$ \\
\hline Upper RT infection & 60 & $(9.8)$ & 54 & $(8.0)$ & 33 & $(4.0)$ & 147 & ( 6.9) \\
\hline Under RT infection & 66 & $(10.8)$ & 42 & $(6.2)$ & 59 & $(7.1)$ & 167 & ( 7.9$)$ \\
\hline Urinary tract infection & 26 & $(4.3)$ & 27 & $(4.0)$ & 13 & $(1.6)$ & 66 & ( 3.1$)$ \\
\hline Perianal abscess & 10 & $(1.6)$ & 10 & $(1.5)$ & 10 & $(1.2)$ & 30 & ( 1.4$)$ \\
\hline Phlegmon & 4 & $(0.7)$ & 10 & $(1.5)$ & 17 & $(2.0)$ & 31 & ( 1.5$)$ \\
\hline Cholecystitis & 3 & $(0.5)$ & 6 & $(0.9)$ & 4 & $(0.5)$ & 13 & $(0.6)$ \\
\hline GIT infection & 1 & $(0.2)$ & 2 & $(0.3)$ & 6 & $(0.7)$ & 9 & $(0.4)$ \\
\hline Peritonitis & 2 & $(0.3)$ & 6 & $(0.9)$ & 0 & $(0.0)$ & 8 & $(0.4)$ \\
\hline Meningitis & 2 & $(0.3)$ & 4 & $(0.6)$ & 0 & $(0.0)$ & 6 & $(0.3)$ \\
\hline Bone $\cdot$ Joint infection & 1 & $(0.2)$ & 2 & $(0.3)$ & 0 & $(0.0)$ & 3 & $(0.1)$ \\
\hline Otitis media & 2 & $(0.3)$ & 0 & $(0.0)$ & 1 & $(0.1)$ & 3 & $(0.1)$ \\
\hline Genital infection & 1 & $(0.2)$ & 1 & $(0.1)$ & 0 & $(0.0)$ & 2 & $(0.1)$ \\
\hline Others & 2 & $(0.3)$ & 0 & $(0.0)$ & 0 & $(0.0)$ & 2 & $(0.1)$ \\
\hline Total & 610 & $(100.0)$ & 674 & $(100.0)$ & 835 & $(100.0)$ & 2119 & $(100.0)$ \\
\hline
\end{tabular}

\section{3. 感染症起炎菌の種類}

起炎菌は532菌株が明らかにされ，その種類を

Table 4 に示した. 全体ではグラム陰性菌 $62.8 \%$, グラム陽性菌 $36.5 \%$ であった。両者の頻度を 3 期
で比較すると,前期 $73.8 \% ： 25.1 \%$,中期 $63.4 \%$ ： $36.1 \%$ とグラム陰性菌の検出率が有意に高かっ た。しかし後期では $47.6 \%: 51.7 \%$ と両者の頻度 は逆転した。グラム陰性菌を菌種別にみると, 
Table 4 Causative organisms

\begin{tabular}{|c|c|c|c|c|c|c|c|c|c|}
\hline & \multirow{2}{*}{ Organisms } & \multicolumn{2}{|c|}{ Former phase } & \multicolumn{2}{|c|}{ Middle phase } & \multicolumn{2}{|c|}{ Late phase } & \multicolumn{2}{|c|}{ Total } \\
\hline & & No. & $(\%)$ & No. & $(\%)$ & No. & $(\%)$ & No. & (\%) \\
\hline \multirow[t]{18}{*}{$\operatorname{Gram}(-)$} & Pseudomonas spp. & 46 & $(24.1)$ & 37 & (19.1) & 30 & $(20.4)$ & 113 & $(21.2)$ \\
\hline & E. coli & 29 & $(15.2)$ & 24 & $(12.4)$ & 12 & $(8.2)$ & 65 & $(12.2)$ \\
\hline & Klebsiella spp. & 21 & $(11.0)$ & 16 & $(8.2)$ & 11 & $(7.5)$ & 48 & $(9.0)$ \\
\hline & Enterobacter spp. & 15 & $(7.9)$ & 7 & $(3.6)$ & 6 & $(4.1)$ & 28 & $(5.3)$ \\
\hline & Proteus spp. & 6 & $(3.1)$ & 7 & $(3.6)$ & 1 & $(0.7)$ & 14 & $(2.6)$ \\
\hline & Serratia spp. & 6 & $(3.1)$ & 5 & $(2.6)$ & 1 & $(0.7)$ & 12 & $(2.3)$ \\
\hline & Acinetobacter spp. & 5 & $(2.6)$ & 6 & $(3.1)$ & & & 11 & $(2.1)$ \\
\hline & Neisseria spp. & 4 & $(2.1)$ & 3 & $(1.5)$ & 1 & $(0.7)$ & 8 & $(1.5)$ \\
\hline & Haemophilus spp. & 4 & $(2.1)$ & 6 & $(3.1)$ & 1 & $(0.7)$ & 11 & $(2.1)$ \\
\hline & Alcaligenes spp. & 1 & $(0.5)$ & 5 & $(2.6)$ & & & 6 & $(1.1)$ \\
\hline & Citrobacter spp. & 1 & $(0.5)$ & 1 & $(0.5)$ & & & 2 & $(0.4)$ \\
\hline & Salmonella spp. & & & 1 & $(0.5)$ & 1 & $(0.7)$ & 2 & $(0.4)$ \\
\hline & Providencia spp. & & & & & 1 & $(0.7)$ & 1 & $(0.2)$ \\
\hline & Campylobacter jejuni & & & & & 1 & $(0.7)$ & 1 & $(0.2)$ \\
\hline & Bacteroides spp. & 1 & $(0.5)$ & & & 1 & $(0.7)$ & 2 & $(0.4)$ \\
\hline & Aeromonas spp. & & & 3 & $(1.5)$ & & & 3 & $(0.6)$ \\
\hline & GNR & 2 & $(1.0)$ & 2 & $(1.0)$ & 3 & $(2.0)$ & 7 & $(1.3)$ \\
\hline & subtotal & 141 & $(73.8)$ & 123 & $(63.4)$ & 70 & $(47.6)$ & 334 & $(62.8)$ \\
\hline \multirow[t]{12}{*}{$\operatorname{Gram}(+)$} & Staphylococcus spp. & 15 & $(7.9)$ & 29 & $(14.9)$ & 31 & $(21.1)$ & 75 & $(14.1)$ \\
\hline & Streptococcus spp. & 17 & $(8.9)$ & 18 & $(9.3)$ & 18 & $(12.2)$ & 53 & $(10.0)$ \\
\hline & Enterococcus spp. & 8 & $(4.2)$ & 19 & $(9.8)$ & 18 & $(12.2)$ & 45 & $(8.5)$ \\
\hline & Bacillus spp. & 5 & $(2.6)$ & & & & & 5 & $(0.9)$ \\
\hline & Corynebacterium spp. & 2 & $(1.0)$ & 2 & $(1.0)$ & 5 & $(3.4)$ & 9 & $(1.7)$ \\
\hline & Micrococcus spp. & 1 & $(0.5)$ & & & & & 1 & $(0.2)$ \\
\hline & Clostridium spp. & & & & & 1 & $(0.7)$ & 1 & $(0.2)$ \\
\hline & Propionibacterium spp. & & & & & 2 & $(1.4)$ & 2 & $(0.4)$ \\
\hline & GPR & & & 2 & $(1.0)$ & 1 & $(0.7)$ & 3 & $(0.6)$ \\
\hline & subtotal & 48 & $(25.1)$ & 70 & $(36.1)$ & 76 & $(51.7)$ & 194 & $(36.5)$ \\
\hline & Candida spp. & 2 & $(1.0)$ & 1 & $(0.5)$ & 1 & $(0.7)$ & 4 & $(0.8)$ \\
\hline & Total & 191 & $(100)$ & 194 & $(100)$ & 147 & $(100)$ & 532 & $(100)$ \\
\hline
\end{tabular}

Pseudomonas 属 $21.2 \%$, E. coli $12.2 \%$, Klebsiella 属 $12.2 \%$, Enterobacter 属5.3\%の順であっ た。これらの菌の 3 期の検出率を比較すると, Pseudomonas属は臣とんど差を認めなかったが, 他は減少傾向を示した。一方，グラム陽性菌は Staphylococcus属14.1\%, Streptococcus属10.0\%, Enterococcus 属8.5\%であった。これら 3 期の検 出率を比較すると，いずれも増加傾向を示した。 すでに述べたように，本研究は細菌感染症を対象 としているので，始めに真菌感染が疑われた例は 除いてあるが, Table に示した Candida 属の検出 は，後になって判明したものである.

a. 敗血症の起炎菌
動脈血あるいは静脈血培養で，2 回以上または 同じ時期に 2 本以上の培養瓶から同じ菌が同定さ れた場合を起炎菌とした。起炎菌は190株検出さ れ，その内訳を Table 5 に示した。 全体でもっと も検出率が高かったのはPseudomonas属 $27.9 \%$, ついで Staphylococcus 属 $16.8 \%$, Streptococcus 属 $11.1 \%$ ，E. coli $10.5 \%$, Klebsiella 属 $8.4 \%$ の 順であった。グラム陰性菌は $58.9 \%$ ，グラム陽性 菌は $40.5 \% て ゙$ 前者が多かったが， 3 期で両者を比 較すると，前期 $63.6 \%: 34.5 \%$ ，中期 $76.4 \%$ : $23.6 \%$ ，後期では $43.8 \%: 56.3 \%$ とグラム陽性菌 が逆転した。敗血症では Pseudomonas 属は減少 傾向を示した。複数菌感染は前期と後期にそれぞ 
Table 5 Causative organisms of sepsis

\begin{tabular}{|c|c|c|c|c|c|c|c|c|c|}
\hline & \multirow{2}{*}{ Organisms } & \multicolumn{2}{|c|}{ Former phase } & \multicolumn{2}{|c|}{ Middle phase } & \multicolumn{2}{|c|}{ Late phase } & \multicolumn{2}{|c|}{ Total } \\
\hline & & No. & (\%) & No. & $(\%)$ & No. & $(\%)$ & No. & (\%) \\
\hline \multirow[t]{14}{*}{$\operatorname{Gram}(-)$} & Pseudomonas spp. & 17 & $(30.9)$ & 22 & $(40.0)$ & 14 & $(17.5)$ & 53 & $(27.9)$ \\
\hline & E. coli & 8 & $(14.5)$ & 6 & $(10.9)$ & 6 & $(7.5)$ & 20 & $(10.5)$ \\
\hline & Klebsiella spp. & 1 & $(1.8)$ & 7 & $(12.7)$ & 8 & $(10.0)$ & 16 & $(8.4)$ \\
\hline & Enterobacter spp. & 3 & $(5.5)$ & 2 & $(3.6)$ & 2 & $(2.5)$ & 7 & $(3.7)$ \\
\hline & Proteus spp. & 1 & $(1.8)$ & & & & & 1 & $(0.5)$ \\
\hline & Serratia spp. & 1 & $(1.8)$ & 1 & $(1.8)$ & & & 2 & $(1.1)$ \\
\hline & Acinetobacter spp. & 3 & $(5.5)$ & 1 & $(1.8)$ & & & 4 & $(2.1)$ \\
\hline & Citrobacter spp. & 1 & $(1.8)$ & & & & & 1 & $(0.5)$ \\
\hline & Salmonella spp. & & & 1 & $(1.8)$ & 1 & $(1.3)$ & 2 & $(1.1)$ \\
\hline & Providencia spp. & & & & & 1 & $(1.3)$ & 1 & $(0.5)$ \\
\hline & Campylobacter jejuni & & & & & 1 & $(1.3)$ & 1 & $(0.5)$ \\
\hline & Aeromonas spp. & & & 2 & $(3.6)$ & & & 2 & $(1.1)$ \\
\hline & GNR & & & & & 2 & $(2.5)$ & 2 & $(1.1)$ \\
\hline & subtotal & 35 & $(63.6)$ & 42 & $(76.4)$ & 35 & $(43.8)$ & 112 & $(58.9)$ \\
\hline \multirow[t]{10}{*}{$\operatorname{Gram}(+)$} & Staphylococcus spp. & 6 & $(10.9)$ & 7 & $(12.7)$ & 19 & $(23.8)$ & 32 & $(16.8)$ \\
\hline & Streptococcus spp. & 6 & $(10.9)$ & 5 & $(9.1)$ & 10 & $(12.5)$ & 21 & $(11.1)$ \\
\hline & Enterococcus spp. & 1 & $(1.8)$ & & & 8 & $(10.0)$ & 9 & $(4.7)$ \\
\hline & Bacillus spp. & 4 & $(7.3)$ & & & & & 4 & $(2.1)$ \\
\hline & Corynebacterium spp. & 2 & $(3.6)$ & 1 & $(1.8)$ & 5 & $(6.3)$ & 8 & $(4.2)$ \\
\hline & Propionibacterium spp. & & & & & 2 & $(2.5)$ & 2 & $(1.1)$ \\
\hline & GPR & & & & & 1 & $(1.3)$ & 1 & $(0.5)$ \\
\hline & subtotal & 19 & $(34.5)$ & 13 & $(23.6)$ & 45 & $(56.3)$ & 77 & $(40.5)$ \\
\hline & Candida spp. & 1 & $(1.8)$ & & & & & 1 & $(0.5)$ \\
\hline & Total & 55 & $(100)$ & 55 & $(100)$ & 80 & $(100)$ & 190 & $(100)$ \\
\hline
\end{tabular}

れ 6 例認められたが，組合せに特徵はみられな かった。

\section{b. 気道感染症の起炎菌}

上気道感染症 147 例, 下気道感染症 167 例中, 起 炎菌として確実あるいは十分可能性があるとされ たのは，前者が75例，後者が105例から検出された 菌であった。検体は病巣から直接採取したものか, 頻回の喀疢である。その内訳を Table 6 に示し た.グラム陰性菌60.0\%，グラム陽性菌38.9\%で， 前期の $74.4 \%, 24.4 \%$ ，後期の $51.4 \% ， 45.9 \%$ の ように,グラム陰性菌が減少傾向を示しているが, Pseudomonas 属だけは前期 $20.5 \%$, 後期 $32.4 \%$ と増加を示した。

なお，発熱例には常に surveillance として咽頭 ぬぐい液中の菌を検索して招り, 889菌株が同定さ れた。これを起炎菌とすることはできないが，口 腔内および上気道感染の傾向を知る上で参考にな
る。全体ではグラム陰性菌 $43.2 \%$ に対しグラム陽 性菌46.7\%であった。もっとも多く検出されたの は Streptococcus 属27.9\%, ついで Staphylococcus 属 $12.5 \%$ で, N eisseria属, 真菌, Pseudomonas 属, Klebsiella 属の順であった.

c. 尿路感染症の起炎菌

臨床的に尿路感染症と診断した症例の尿中細菌 をTable 7 に示した. 87菌株で実際の症例数より も多いのは，同一症例で 2 種以上の菌が検出され たためである。全体でグラム陰性菌は $70.1 \%$ ，グ ラム陽性菌は $29.9 \%$ あった。 もっとも多かった のはE. coli, ついでEnterococcus 属, Pseudomonas 属の順であった。時期別の推移をみると, 後期でグラム陰性菌が著明に減少した。混合感染 の菌種の組合せに特徵はみ出せなかった。

d. 糞便中の菌種

発熱例の surveillance として検索した糞便中 
Table 6 Causative organisms of respiratory tract infection

\begin{tabular}{|c|c|c|c|c|c|c|c|c|c|}
\hline & \multirow{2}{*}{ Organisms } & \multicolumn{2}{|c|}{ Former phase } & \multicolumn{2}{|c|}{ Middle phase } & \multicolumn{2}{|c|}{ Late phase } & \multicolumn{2}{|c|}{ Total } \\
\hline & & No. & (\%) & No. & (\%) & No. & $(\%)$ & No. & (\%) \\
\hline \multirow[t]{13}{*}{$\operatorname{Gram}(-)$} & Pseudomonas spp. & 16 & $(20.5)$ & 10 & $(15.4)$ & 12 & $(32.4)$ & 38 & $(21.1)$ \\
\hline & E. coli & 6 & $(7.7)$ & 3 & $(4.6)$ & 1 & $(2.7)$ & 10 & $(5.6)$ \\
\hline & Klebsiella spp. & 14 & $(17.9)$ & 2 & $(3.1)$ & 3 & $(8.1)$ & 19 & $(10.6)$ \\
\hline & Enterobacter spp. & 7 & $(9.0)$ & 4 & $(6.2)$ & 2 & $(5.4)$ & 13 & $(7.2)$ \\
\hline & Proteus spp. & 1 & $(1.3)$ & & & & & 1 & $(0.6)$ \\
\hline & Serratia spp. & 3 & $(3.8)$ & & & & & 3 & $(1.7)$ \\
\hline & Acinetobacter spp. & 2 & $(2.6)$ & 1 & $(1.5)$ & & & 3 & $(1.7)$ \\
\hline & Neisseria spp. & 4 & $(5.1)$ & 3 & $(4.6)$ & & & 7 & $(3.9)$ \\
\hline & Heamophilus spp. & 4 & & 6 & $(9.2)$ & 1 & $(2.7)$ & 11 & $(6.1)$ \\
\hline & Citrobacter spp. & & & 1 & $(1.5)$ & & & 1 & $(0.6)$ \\
\hline & Bacteroides spp. & 1 & $(1.3)$ & & & & & 1 & $(0.6)$ \\
\hline & Fusobacterium spp. & & & 1 & $(1.5)$ & & & 1 & $(0.6)$ \\
\hline & subtotal & 58 & $(74.4)$ & 31 & $(47.7)$ & 19 & $(51.4)$ & 108 & $(60.0)$ \\
\hline \multirow[t]{7}{*}{$\operatorname{Gram}(+)$} & Staphylococcus spp. & 7 & $(9.0)$ & 15 & $(23.1)$ & 7 & $(18.9)$ & 29 & $(16.1)$ \\
\hline & Streptococcus spp. & 9 & (11.5) & 11 & $(16.9)$ & 7 & $(18.9)$ & 27 & $(15.0)$ \\
\hline & Enterococcus spp. & 2 & $(2.6)$ & 8 & $(12.3)$ & 3 & $(8.1)$ & 13 & $(7.2)$ \\
\hline & Corynebacterium spp. & 1 & $(1.3)$ & & & & & 1 & $(0.6)$ \\
\hline & subtotal & 19 & $(24.4)$ & 34 & $(52.3)$ & 17 & $(45.9)$ & 70 & $(38.9)$ \\
\hline & Candida spp. & 1 & $(1.3)$ & & & 1 & $(2.7)$ & 2 & $(1.1)$ \\
\hline & Total & 78 & $(100)$ & 65 & $(100)$ & 37 & $(100)$ & 180 & $(100)$ \\
\hline
\end{tabular}

Table 7 Causative organisms of urinary tract infection

\begin{tabular}{|c|c|c|c|c|c|c|c|c|c|}
\hline & \multirow{2}{*}{ Organisms } & \multicolumn{2}{|c|}{ Former phase } & \multicolumn{2}{|c|}{ Middle phase } & \multicolumn{2}{|c|}{ Late phase } & \multicolumn{2}{|c|}{ Total } \\
\hline & & No. & $(\%)$ & No. & $(\%)$ & No. & $(\%)$ & No. & (\%) \\
\hline \multirow[t]{10}{*}{$\operatorname{Gram}(-)$} & Pseudomonas spp. & 6 & $(21.4)$ & 4 & $(9.3)$ & 3 & $(18.8)$ & 13 & $(14.9)$ \\
\hline & E. coli & 7 & $(25.0)$ & 8 & $(18.6)$ & 3 & $(18.8)$ & 18 & $(20.7)$ \\
\hline & Klebsiella spp. & 1 & $(3.6)$ & 6 & $(14.0)$ & & & 7 & $(8.0)$ \\
\hline & Enterobacter spp. & 4 & (14.3) & & & & & 4 & $(4.6)$ \\
\hline & Proteus spp. & 2 & $(7.1)$ & 2 & $(4.7)$ & 1 & $(6.3)$ & 5 & $(5.7)$ \\
\hline & Serratia spp. & 2 & $(7.1)$ & 4 & $(9.3)$ & 1 & $(6.3)$ & 7 & $(8.0)$ \\
\hline & Alcaligenes spp. & 1 & $(3.6)$ & 1 & $(2.3)$ & & & 2 & $(2.3)$ \\
\hline & Acinetobacter spp. & & & 4 & $(9.3)$ & & & 4 & $(4.6)$ \\
\hline & GNR & & & 1 & $(2.3)$ & & & 1 & $(1.1)$ \\
\hline & subtotal & 23 & $(82.1)$ & 30 & $(69.8)$ & 8 & $(50.0)$ & 61 & $(70.1)$ \\
\hline \multirow[t]{7}{*}{$\operatorname{Gram}(+)$} & Staphylococcus spp. & & & 4 & $(9.3)$ & 2 & $(12.5)$ & 6 & ( 6.9) \\
\hline & Streptococcus spp. & 1 & $(3.6)$ & & & 1 & $(6.3)$ & 2 & $(2.3)$ \\
\hline & Enterococcus spp. & 4 & $(14.3)$ & 7 & $(16.3)$ & 5 & $(31.3)$ & 16 & $(18.4)$ \\
\hline & Corynebacterium spp. & & & 1 & $(2.3)$ & & & 1 & $(1.1)$ \\
\hline & GPR & & & 1 & $(2.3)$ & & & 1 & $(1.1)$ \\
\hline & subtotal & 5 & $(17.9)$ & 13 & $(30.2)$ & 8 & $(50.0)$ & 26 & $(29.9)$ \\
\hline & Total & 28 & $(100)$ & 43 & $(100)$ & 16 & $(100)$ & 87 & $(100)$ \\
\hline
\end{tabular}

から, 424菌株が検出され, その内訳を Table 8 に 示した.グラム陰性菌52.6\%,グラム陽性菌40.8\%
であったが，時期別にみると，後期にはグラム陽 性菌の方が高い検出率であった。もっとも多かっ 
Table 8 Bacilli in feces

\begin{tabular}{|c|c|c|c|c|c|c|c|c|c|}
\hline & \multirow{2}{*}{ Organisms } & \multicolumn{2}{|c|}{ Former phase } & \multicolumn{2}{|c|}{ Middle phase } & \multicolumn{2}{|c|}{ Late phase } & \multicolumn{2}{|c|}{ Total } \\
\hline & & No. & (\%) & No. & (\%) & No. & $(\%)$ & No. & (\%) \\
\hline \multirow[t]{13}{*}{$\operatorname{Gram}(-)$} & Pseudomonas spp. & 14 & $(10.4)$ & 7 & $(4.3)$ & 7 & $(5.5)$ & 28 & $(6.6)$ \\
\hline & E. coli & 22 & $(16.3)$ & 27 & $(16.7)$ & 11 & $(8.7)$ & 60 & $(14.2)$ \\
\hline & Klebsiella spp. & 19 & (14.1) & 19 & (11.7) & 7 & $(5.5)$ & 45 & $(10.6)$ \\
\hline & Enterobacter spp. & 18 & (13.3) & 9 & $(5.6)$ & 6 & $(4.7)$ & 33 & $(7.8)$ \\
\hline & Proteus spp. & 10 & $(7.4)$ & 11 & $(6.8)$ & 7 & $(5.5)$ & 28 & $(6.6)$ \\
\hline & Serratia spp. & 5 & ( 3.7$)$ & 5 & $(3.1)$ & 2 & $(1.6)$ & 12 & $(2.8)$ \\
\hline & Alcaligenes spp. & 1 & $(0.7)$ & & & & & 1 & $(0.2)$ \\
\hline & Citrobacter spp. & 3 & $(2.2)$ & 3 & ( 1.9$)$ & 3 & $(2.4)$ & 9 & $(2.1)$ \\
\hline & Salmonella spp. & & & & & 1 & $(0.8)$ & 1 & $(0.2)$ \\
\hline & Providencia spp. & & & & & 3 & $(2.4)$ & 3 & $(0.7)$ \\
\hline & Bacteroides spp. & 2 & $(1.5)$ & & & & & 2 & $(0.5)$ \\
\hline & Aeromonas spp. & & & 1 & $(0.6)$ & & & 1 & $(0.2)$ \\
\hline & subtotal & 94 & $(69.6)$ & 82 & $(50.6)$ & 47 & $(37.0)$ & 223 & $(52.6)$ \\
\hline \multirow[t]{10}{*}{$\operatorname{Gram}(+)$} & Staphylococcus spp. & 7 & $(5.2)$ & 7 & $(4.3)$ & 4 & $(3.1)$ & 18 & $(4.2)$ \\
\hline & Streptococcus spp. & 2 & $(1.5)$ & 6 & $(3.7)$ & 5 & ( 3.9$)$ & 13 & $(3.1)$ \\
\hline & Enterococcus spp. & 23 & $(17.0)$ & 57 & $(35.2)$ & 59 & $(46.5)$ & 139 & $(32.8)$ \\
\hline & Corynebacterium spp. & 1 & $(0.7)$ & & & & & 1 & $(0.2)$ \\
\hline & Clostridium spp. & 1 & $(0.7)$ & & & & & 1 & $(0.2)$ \\
\hline & GPR & & & 1 & $(0.6)$ & & & 1 & $(0.2)$ \\
\hline & subtotal & 34 & $(25.2)$ & 71 & $(43.8)$ & 68 & $(53.5)$ & 173 & $(40.8)$ \\
\hline & Candida spp. & 2 & $(1.5)$ & 4 & $(2.5)$ & 9 & $(7.1)$ & 15 & $(3.5)$ \\
\hline & Fungus & 5 & $(3.7)$ & 5 & $(3.1)$ & 3 & $(2.4)$ & 13 & $(3.1)$ \\
\hline & Total & 135 & $(100)$ & 162 & $(100)$ & 127 & $(100)$ & 424 & $(100)$ \\
\hline
\end{tabular}

Table 9 Clinical effectiveness of antibiotics

\begin{tabular}{lrclcr}
\hline \multicolumn{1}{c}{ Drugs } & $\begin{array}{c}\text { No. of } \\
\text { case }\end{array}$ & $\begin{array}{c}\text { Efficacy rate } \\
(\%)\end{array}$ & \multicolumn{1}{c}{ Drugs } & $\begin{array}{c}\text { No. of } \\
\text { case }\end{array}$ & $\begin{array}{c}\text { Efficacy rate } \\
\text { (\%) }\end{array}$ \\
\hline 1. Amikacin(AMK) & 35 & $23(65.7)$ & 14. Micronomicin(MCR) & 66 & $29(43.9)$ \\
2. Piperacillin(PIPC) & 45 & $20(44.4)$ & 15. Cefpiramide(CPM) & 55 & $33(60.0)$ \\
3. Cefmetazole(CMZ) & 51 & $28(54.9)$ & 16. Aspoxicillin(ASPC) & 58 & $29(50.0)$ \\
4. Cefoxitin(CFX) & 64 & $39(60.9)$ & 17. Cefminox(CMNX) & 62 & $32(51.6)$ \\
5. Ticarcillin(TIPC) & 58 & $39(67.2)$ & 18. Cefmenoxime(CMX) & 91 & $55(60.4)$ \\
6. Tobramycin(TOB) & 64 & $32(50.0)$ & 19. Aztreonam(AZT) & 90 & $46(51.1)$ \\
7. Cefotetan(CTT) & 66 & $38(57.6)$ & 20. Cefbuperazone(CBPZ) & 78 & $46(59.0)$ \\
8. Cefotiam(CTM) & 102 & $53(52.0)$ & 21. Sulbactam/Cefoperazone(SBT/CPZ) & 76 & $40(52.6)$ \\
9. Latamoxef(LMOX) & 73 & $44(60.3)$ & 22. Ceftriaxone(CTRX) & 70 & $38(54.3)$ \\
10. Fosfomycin(FOM) & 65 & $35(53.8)$ & 23. Aztreonam+Clindamicin & 53 & $34(64.2)$ \\
11. Cefotaxime(CTX) & 75 & $41(54.7)$ & 24. Amikacin+Aztreonam & 53 & $28(52.8)$ \\
12. Cefoperazone(CPZ) & 80 & $41(51.3)$ & 25. Clindamicin +Amikacin & 54 & $19(35.2)$ \\
13. Ceftizoxime(CZX) & 84 & $52(61.9)$ & 26. Imipenem/Cilastatin(IPM/CS) & 182 & $102(56.0)$ \\
\hline
\end{tabular}

たのは Enterococcus 属で，前期 $17.0 \%$ ，中期 $35.2 \%$ ，後期 $46.5 \%$ と著明に増加した。ついで多 かったのはE. coli であったが, 後期はかなり減少 した。

\section{4. 抗生剂の臨床的効果}

単独投与 23 種類と 2 剂併用投与 3 方法の有効率 を Table 9 に示した. 治験が行われた順に並べて あるが, 有効率は各薬剤によって差があり, $43.9 \%$ 
Table 10 Relation between efficacy rate and neutrophil counts after administration of antibiotics

\begin{tabular}{|c|c|c|c|c|c|}
\hline Drugs & $\begin{array}{l}\text { No. of } \\
\text { case }\end{array}$ & $\begin{array}{c}\leqq 500 \\
\text { No. }(\%)\end{array}$ & $\begin{array}{c}\text { Efficacy rate } \\
\text { No. (\%) }\end{array}$ & $\begin{array}{c}\leqq 100 \\
\text { No. }(\%)\end{array}$ & $\begin{array}{c}\text { Efficacy rate } \\
\text { No. }(\%)\end{array}$ \\
\hline AMK & 32 & $14(43.8)$ & $7(50.0)$ & $6(18.8)$ & $2(33.3)$ \\
\hline PIPC & 43 & $14(32.6)$ & $6(42.9)$ & $5(11.6)$ & $2(40.0)$ \\
\hline $\mathrm{CMZ}$ & 47 & $17(36.2)$ & $5(29.4)$ & $7(14.9)$ & $3(42.9)$ \\
\hline $\mathrm{CFX}$ & 63 & $20(31.7)$ & $10(50.0)$ & $8(12.7)$ & $3(37.5)$ \\
\hline TIPC & 42 & $13(31.0)$ & $6(46.2)$ & $5(11.9)$ & $2(40.0)$ \\
\hline TOB & 51 & $18(35.3)$ & $9(50.0)$ & $5(9.8)$ & $2(40.0)$ \\
\hline СTT & 64 & $19(29.7)$ & $8(42.1)$ & $10(15.6)$ & $3(30.0)$ \\
\hline CTM & 66 & $17(25.8)$ & $3(17.6)$ & $6(9.1)$ & $0(0.0)$ \\
\hline LMOX & 73 & $34(46.6)$ & $17(50.0)$ & $14(19.2)$ & $7(50.0)$ \\
\hline FOM & 53 & $14(26.4)$ & $8(57.1)$ & $4(7.5)$ & $2(50.0)$ \\
\hline CTX & 74 & $29(39.2)$ & $10(34.5)$ & $11(14.9)$ & $2(18.2)$ \\
\hline $\mathrm{CPZ}$ & 80 & $35(43.8)$ & $17(48.6)$ & $16(20.0)$ & $6(37.5)$ \\
\hline CZX & 81 & $34(42.0)$ & $15(44.1)$ & $21(25.9)$ & $7(33.3)$ \\
\hline MCR & 66 & $37(56.1)$ & $13(35.1)$ & $25(37.9)$ & 7. (28.0) \\
\hline CPM & 48 & $22(45.8)$ & $14(63.6)$ & $13(27.1)$ & $6(46.2)$ \\
\hline ASPC & 58 & $27(46.6)$ & $13(48.1)$ & $13(22.4)$ & $3(23.1)$ \\
\hline CMNX & 62 & $34(54.8)$ & $16(47.1)$ & $16(25.8)$ & $4(25.0)$ \\
\hline CMX & 91 & $40(44.0)$ & $21(52.5)$ & $16(17.6)$ & $8(50.0)$ \\
\hline $\mathrm{AZT}$ & 90 & $39(43.3)$ & $15(38.5)$ & $22(24.4)$ & $5(22.7)$ \\
\hline CBPZ & 78 & $31(39.7)$ & $17(54.8)$ & $19(24.4)$ & $8(42.1)$ \\
\hline $\mathrm{SBT} / \mathrm{CPZ}$ & 74 & $32(43.2)$ & $13(40.6)$ & $18(24.3)$ & $8(44.4)$ \\
\hline CTRX & 70 & $28(40.0)$ & $13(46.4)$ & $13(18.6)$ & $5(38.5)$ \\
\hline IPM/CS & 176 & $90(51.1)$ & $49(54.4)$ & $43(24.4)$ & $17(39.5)$ \\
\hline $\mathrm{AZT}+\mathrm{CLDM}$ & 53 & $29(54.7)$ & $15(51.7)$ & $15(28.3)$ & $7(46.7)$ \\
\hline $\mathrm{AMK}+\mathrm{AZT}$ & 52 & $30(57.7)$ & $15(50.0)$ & $15(28.8)$ & $6(40.0)$ \\
\hline \multirow[t]{2}{*}{$\mathrm{CLDM}+\mathrm{AMK}$} & 54 & $23(42.6)$ & $5(21.7)$ & $15(27.8)$ & $3(20.0)$ \\
\hline & 1741 & $740(42.5)$ & $340(45.9)$ & $361(20.7)$ & $130(36.0)$ \\
\hline
\end{tabular}

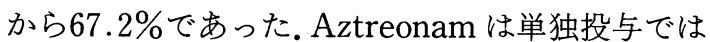
51.1\%を示したが, Clindamycinとの併用で $64.2 \%$ に昇した。一方, Amicacin は単独投与で 65.7\%と高率であったが, Aztreonam と併用する と $52.8 \%$ にった。

\section{5. 末梢好中球数と有効率との関係}

抗生剂を投与する前と後の末梢血好中球数を比 較し，有効率との関係を検討した。投与後とは, 抗生剂の効果が現われ, 著効または有効と判定し た時点あるいは他剤に変更した時点である。好中 球数の平均值は，投与前が $170 / \mu 1$, 投与後が $292 /$ $\mu 1$ であった。一部の薬剤ではリンパ球数について も比較したが，至とんど差を認めなかった。一般 に抗生剂投与後好中球数が増加する例で有効率が 高くなる傾向を示した ${ }^{2) ~ 6) . ~}$
抗生剂を投与する前に比べて，投与後も好中球 数が変化しなかった，つまり増加しなかった例に ついて，それぞれの薬剤の有効率を検討したのが Table 10 である.好中球数が定期的に算定されて いる評価可能な 1,741 例中, 抗生剤投与前後の好中 球数が $500 / \mu 1$ 以下の例は 740 例 $(42.5 \%$ ) であっ た。その中で有効以上に判定されたのは340例で, 平均有効率は $45.9 \%$ であった。各薬剤別にみると， 好中球数 $500 / \mu 1$ 以下の症例が $50 \%$ 以上を占めて いたにも拘らず, 有効率が平均以上であったのは, 単独では CMNX と IPM/CS だけであり, 併用で は AZT+CLDM, AMK+AZTであった。さらに 基準を下げて, 好中球数 $500 / \mu 1$ 以下の症例が 40４9\%を占めて有効率が平均以上を示した薬剂 は, AMK, LMOX, CPZ, CPM, ASPC, CMX 
および CTRX であった。な拉，抗生剂投与後も好 中球が $100 / \mu 1$ 以下であった症例は361例 $(20.7 \%)$ であり，その有効率は $36.5 \%$ を示した。

\section{総括ならびに考案}

造血器疾患に重症感染症が合併しやすい理由と して，疾患自体あるいは強力な抗腫瘍剤投与の影 響による好中球の数と機能の低下があげられる. このような感染症の実態を把握し，適切な治療法 を検討することを目的に，1979年に阪神地区の施 設で研究グループを結成した。 今までに扱った抗 菌剤の成績については，その都度報告してきた。 本論文では, 10 年間の症例 2,119 例の細菌感染症と 各種抗生剂の効果をまとめて検討した結果を述べ た。

造血器疾患に合併する感染症でもっとも多かっ たのは敗血症疑いで，68.6\%に認められた。これ は発熱しても感染病巣が明らかでなく, 薬剤や輸 血などの副作用，腫瘍による熱などを除いたもの に名づけている，不明熱としなかったのは，抗生 剂を投与すると60〜 70\%が，抗真菌剤を投与する と約 $15 \%$ が解熱すること, 死亡例の剖検所見で感 染病巣が明らかにされ，これが直接死因と考兄ら れる例が多いこと，汪とんどが好中球減少時に発 症すること7などが理由である。しかし，敗血症疑 いに含めた全例を感染症とするには問題があり， さらに解析をする必要がある。

Pennington ${ }^{8)}$ による, 好中球数が減少した悪 性腫瘍患者の発熱例で，起炎菌が同定されたのは $21 \%$, 臨床症状から感染の可能性を考えたのは $33 \%$, 特別な症状がなく, 発熱のみが $46 \%$ であっ たという。つまり $79 \%$ が敗血症疑いに相当するも のであった. Sikles ら) も報告しているよらに, 著 明に好中球が減少した患者に合併する感染症は, 発熱だけで局所症状に乏しく，また起炎菌が検出 しにくいことは, われわれも指摘して抢り ${ }^{10)}$, 造血 器疾患の感染症の大きな特徵といえる。

気道感染症は，20年前には $60 \%$ 以上を占めてい たが，徐々に減少傾向を示し，前期 $20.6 \%$ から後 期11.1\%になった。この理由は, 無菌環境下での 管理が普及したこと, 経気道感染予防の知識が向 上したこと，および第三世代のセフェム系抗生剂
が使用され，グラム陰性菌感染が減少したことな どがあげられる。しかし，Pseudomonas 属感染だ けは減少していない。

敗血症拉よび敗血症疑いは減少傾向を示さな かった。この理由として, 経中心静脈栄養補給が 普及したため, 静脈内留置カテーテルが感染源と して増えたこと，最近は抗腫瘍剤の多剂併用療法 が強力になっていることなどが考えられた。一方, 無菌環境下で管理した場合とそうでない場合を比 較しても，敗血症の併発率に差がないことか $ら^{1112)}$, これらの起炎菌が常在菌による内因性感 染である可能性が十分考兄られる，従って，もっ とも考学られる感染源である腸内細菌について は，非吸収性の抗菌剤の投与などが試みられてい る ${ }^{13)}$. 朝野 ${ }^{14)}$ は免疫抑制状態に発症する敗血症の 機序として，腸管細菌叢から門脈を介して血行性 に，またリンパ装置を介してリンパ行性に拡がる 経路があることを証明している。

感染症を併発した 2,119 例から532菌株が同定さ れた。グラム陰性菌62.8\%，グラム陽性菌 $36.5 \%$ であったが，最近 4 年間の後期だけをみると，グ ラム陽性菌の方が多くなっている。これは第三世 代のセフェム系抗生剂が使用されてからの現象で ある.グラム院性菌の中では, Pseudomonas 属だ けが減少しなかったことは，現在の抗生剤では本 菌に対する抗菌力が十分でないことを示してい る.

起炎菌の混合感染については, Whimbey $ら^{15)}$ が報告しているように，悪性腫瘍患者で白血球数 減少例に多く認められている。彼らによると敗血 症の $21 \%$ が複数菌によるもので, Enterococcus 属 と Corynebacterium 属は $80 \%$ が, S. epidermidis は70\%が片方の起炎菌になっているという．われ われの検索では, 敗血症で $6.7 \%$, 尿路感染症で $41.4 \%$ が複数菌感染であった。しかし，菌種の組 合せに特徵はみられなかった。

末梢好中球数と抗生剂の効果は密接に関係して いる. 長谷川 ${ }^{16)}$ は血液疾患感染合併例214例につい て，15種の抗生物質投与前後の好中球数と臨床効 果について検討した。その結果, 投与前の好中球 数は有効率に影響が少なく，むしろ投与後の好中 
球数の変動が関係し, とくに好中球が nadir 期か ら回復して増加する過程で抗生剂の効力が強く発 揮される事実を証明した。今回使用した 23 種の抗 生剂の単独投与の有効率は50\%台が多かったが, 好中球数が $100 / \mu 1$ 以下で増加傾向を示さない時 期にも平均 $36 \%$ の有効率を示した。 この有効率を さらに向上させるために, 今後はそれぞれの抗生 剤の特徵を生かした併用療法について検討する予 定である。な拉, 各抗生剂の疾患別执よび細菌学 的効果については，それぞれの薬剤別に発表ずみ である。

\section{文献}

1）高久史䵇, 永井清保, 前川 正, 正岡 徹：顆粒 球減少に伴う感染症に対する抗菌薬の効果判定基 準。臨床血液, 25 : 588-592, 1984.

2）永井清保, 金丸昭久, 正岡 徹, 植田高彰, 柴田 弘俊, 木谷照夫, 椿尾忠博, 米沢 毅, 川越裕也, 篠原慶希, 堀内 篤, 長谷川廣文, 那須輝史 : 血 液疾患合併重症感染症に対する Tobramycin 大 量点滴投与に上る臨床効果と安全性の検討. 最新 医学, 36:2009-2015, 1981.

3）長谷川廣文, 堀内 篤, 永井清保, 金丸昭久, 正 岡 徹, 柴田弘俊, 木谷照夫, 椿尾忠博, 川越裕 也, 篠原慶希, 那須輝史 : 造血器疾患に合併した 重症感染症に対する Cefoxitinの効果. Jap. J. Antivio., 35 : 1212-1222, 1982.

4）金丸昭久, 永井清保, 正岡 徹, 柴田弘俊, 木谷 照夫, 谷口信博, 堀内 篤, 長谷川廣文, 川越裕 也, 平田充彦, 岡本緩子, 藤竹英樹, 米沢 毅, 金山良男：血液疾患に合併した重症感染症に対す る Ceftizoxime の臨床効果と安全性の検討. Jap. J. Antibio., 37 : 136-144, 1984.

5）陰山 克, 大藪 博, 正岡 徹, 柴田弘俊, 永井 清保, 木谷照夫, 堀内 篤, 川越裕也, 安永幸二 郎, 米沢 毅：血液疾患に合併した重症感染症に 対する Cefbuperazone の有用性と安全性の検討. Jap. J. Antibio., 41 : 312-321, 1988.

6) Horiuchi, A., Hasegawa, H., Kageyama, T., Yonezawa, T., Kitani, T., Masaoka, T.,
Yasunaga, K., Kawagoe, H. \& Nagai, K.: Efficacy of sulbactam/cefoperazone for infections in patients with hematological diseases. Diag. Micro. Infec. Dis., 12(Suppl). : 215-219, 1989.

7) 正岡 徹：白血病に打ける感染症と対策. 医学の あゆみ, 128: 1026一-1030, 1984.

8) Pennington, J.E.: Fever, neutropenia and malignancy : A clinical syndrome in evolution. Cancer, 39: 1345-1349, 1977.

9) Sickles, E.A., Greene, W.H. \& Wiernik, P.H. : Clinical presentation of infection in granulocytopenic patients. Arch. Intern. Med., 135 : 715-719, 1975.

10) 堀内 篤: 造血器腫瘍の化学療法と感染. chemotherapy, $26: 697-699,1978$.

11）堀内 篤, 長谷川廣文, 橋村俊一, 岩永隆行: 顆 粒球減少時に扔ける易感染状態の臨床的研究. 近 大医誌, 4:29-38, 1979.

12) Ueda, T., Shibata, H., Nakamura, H., Takubo, T., Kubota, Y., Ogawa, S., Tani, Y., Masaoka, T., Nagano, T., Takeo, H., Hasegawa, H. \& Moriyama, Y.: Efficacy of laminar air flow room with or without clean nursing for preventing infection in patients with acute leukemia. Jap. J. Clin. Oncol., 13(Suppl.) : 151-158, 1983.

13）芦田隆司, 長谷川廣文, 椿 和央, 岩永隆行, 入 交清博, 堀内 篤: 易感染状態にある血液疾患患 者に対する非吸収性抗生物質の予防的投与。感染 症誌, 59: 1198-1203, 1985.

14）朝野和典：免疫抑制状態に発症する敗血症の発症 機序と予防。第 1 報：免疫抑制マウス敗血症発症 機序の解明. 感染症誌, 63:479-487, 1989.

15) Whimbey, E., Kiehn, T.E., Brannon, P., Blevins, A. \& Armstrong, D.: Bacteremia and fungemia in patients with neoplastic disease. Am. J. Med., 82: 723-730, 1987.

16）長谷川廣文：造血器疾患に合併した重症感染症に 扣ける各種抗生物質の治療効果之好中球数の影 響. 近大医誌, $9: 503-515,1984$. 
Actual Conditions of Bacterial Infection associated with Hematopoietic Disorders - Change of 10 Years-

The Hanshin Study Group of hematopoietic Disorders and Infections

(Manager: Kiyoyasu NAGAI)

Atsushi HORIUCHI \& Hirofumi HASEGAWA

The Third Department of Internal Medicine, Kiniki University School of Medicine

Tohru MASAOKA \& Hirotoshi SHIBATA

Department of Internal Medicine, The Center for Adult Diseases, Osaka

Teruo KITANI \& Shinichi TAGAWA

Division of Internal Medicine, Department of Clinical Research, Research Institute for Microbial Diseases, Osaka University

Hiroya KAWAGOE \& Mitsuhiko HIRATA

Department of Internal Medicine, Osaka National Hospital

Tsuyoshi YONEZAWA \& Yohsio KANAYAMA

The Second Department of Internal Medicine, Medical School, Osaka University

Noriyuki TATSUMI \& Taisei NIN

Department of Laboratory Medicine, Osaka City University Medical School

Takashi KAGEYAMA \& Hiroshi OHYABU

The Second Department of Internal Medicine, Osaka Medical College

Kiyoshi AKASAKA \& Kaori NASU

Department of Internal Medicine, Osaka Red Cross Hospital

Kohjiro YASUNAGA \& Hideki FUJITAKE

The First Department of Internal Medicine, Kansai Medical University

kiyoyasu NAGAI \& Akihisa KANAMARU

The Second Department of Internal Medicine, Hyogo College of Medicine

This study showed several accumulated data through ten years from our experience in hematopoietic disorders and associated infections, which has been analyzed by the Hanshin Study Group of Hematopoietic Disorders and Infections.

Since 1979 to 1988, our group had evaluated the sorts of causative organisms and the efficacy of various antibiotics therapy in 2119 cases of infectious diseases associated with hematopoietic disorders. On behalf of evaluating the changes of disease profile for ten years, we divided the accumulated data into three phases; former phase the first three years, middle phase the second three years and late phase the last four years.

There was no significant difference in the frequency of various hematopoietic disorders among the three phases. Each leukemia patients occupied $77 \%$ of all cases. Sepsis suspected is the most frequent infectious disease accounting for $68.8 \%$. The other infectious diseses were $8.4 \%$ of the sepsis, $14.8 \%$ of the respiratory infections and $3.1 \%$ of the urinary tract infections. Comparing the frequency of infections among the three phases, the respiratory and urinary tract infections inclined to decrease.

Of the 532 strains isolated from 2119 cases and identified as causative organisms, gram-negative bacilli occupied $62.8 \%$ and gram-positive bacteria $36.5 \%$. In comparing the percentage of gram-negative bacilli among the three phases, it showed a decreasing tendency in order former phase $63.6 \%$, middle phase $76.4 \%$ and late phase $43.8 \%$. Pseudomonas, however, had been isolated at almost constant ratio through ten years. On the other hand, the ratio of gram-positive bacteria isolated were $34.5 \%$ in former phase, $23.6 \%$ in middle phase and $56.3 \%$ in late phase, showing increasing a tendency through the period.

Twenty-three kinds of antibiotics were administered by intravenous drip infusion. The efficacy rate was $43.9 \%$ to $67.2 \%$, In paticular, effectiveness of antibiotic therapy often depends on the change of peripheral neutrophil counts from the onset and during the therapy. The efficacy rate, however, was $36 \%$ even neutrophil counts have not shown the tendency of increase from less than $100 / \mu$. 